\title{
DISCOURSE: CRIMINAL LIABILITY FOR THE FAILURE OF NATIONAL / REGIONAL DEVELOPMENT PLANNING
}

\author{
Taufik Hidayat \\ Lembaga Ilmu Pengetahuan Indonesia (LIPI) \\ Email:taufikumsu@yahoo.com
}

\author{
ARTICLE INFORMATION \\ Article history: \\ Received July 11, 2015 \\ Revised November 26, 2015 \\ Accepted February 29, 2016

\section{JEL Classifications} \\ $\mathrm{K} 40$
}

\section{Key Words:}

Discourse,

Criminal Liability,

Fraud,

National/Regional Development

Planning

\section{DOI:}

10.21532/apfj.001.16.01.01.11

\begin{abstract}
National / Regional Development Planning (PPN/D) is a derivation of political promises of the head of state / region, hence the National and Regional Development Planning tends to be momentary interests of the head of state / region and / or elitists around him. The National and Regional Development Planning which is put into the program and made as a project can be colored by the elements of corruption, collusion and nepotism and that the program / project is likely to be executed at random. The liability for acts of corruption, collusion, and nepotism that leads to the failure of the National / Regional Development Planning is still noticeably blurry and so light, and limited only when the accountability report of the implementation of the National and Regional Development Planning is declared "rejected", then the head of state / region concerned would be requested to fix it and / or he could no longer run. On the other hand, the National / Regional Development Planning must have used a large number of resources, so it is interesting to see more deeply, such as the possibility of criminal sanctions which can be imposed as a "deterrent" of a bad faith of the whole process National / Regional Development Planning. Based on those mentioned above, this paper will discuss the possibility to request criminal liability for the failure of the National / Regional Development Planning. The research method used is qualitative descriptive, using secondary data, a literature search. Since the head of state/region is the responsibility center of the government administration, the head of state I region must be responsible for the implementation of National / Regional Development Planning. The rejection of the accountability report presented by the head of state I region is a measure of the failure of the National/Regional Development Planning. Since the National / Regional Development Planning is a derivation of the political promises of the head of state / region at the time of the election campaign, the criminal offenses of fraud could be
\end{abstract}


made as the basis of criminal liability for the failure of the National / Regional Development.

\section{INTRODUCTION}

The Head of Center for Development, Education and Training of Planner -National Development Planning Agency / Pusbindiklatren Bappenas, Yahya Rachmana Hidayat (2014) in his presentation at the Public Lecture of Master Program in Public Administration of Brawijaya University school year 2014/2015, in accordance with the expression of a philosopher, Plato, as quoted by Eriyatno (2002), in the Workshop on Strengthening SMEs to Accelerate Policy Reform Agenda, stated that "the most important part of the work is in the beginning". In other words, process and substance of a planning play a very important role in development activities. High quality planning will be able to guarantee the success of a program. Conversely, if the planning is done at random, the performance of the program will certainly be low or totally fail, moreover when it is linked to the complexity of the program itself.

As well as the development in Indonesia, the role of National / Regional Development Planning is very important in ensuring the success of all programs to achieve the goals of the State as stated in the preamble of the 1945 Constitution, ie. to realize a just and prosperous society. In the National / Regional Development Planning, one of which contains National and Regional Medium Term Development Plan (RPJMN/D) which includes the vision, mission, and program of
The Head of State / Region. The formulation is based on the National / Regional Long Term Development Plan containing the direction of financial policy, development strategy, public policy, and regional program accompanied by work plans within the regulatory framework and indicative funding framework (Article 5, paragraph 2 of Law No. 25 of 2004 on National Development Planning System). While the Government Work Plan (RKP) is the elaboration of National and Regional Medium Term Development Plan (RPJMN / D) containing the proposed framework for the economy, regional development priorities, work plans, and funding, either implemented directly by the government or taken by empowering public participation (Article 5, paragraph 2 of Law No. 25 of 2004 on National Development Planning System). Based on these two provisions, the National / Regional Development Planning as outlined in the National and Regional Medium Term Development Plan (RPJMN / D) and the Government Work Plan (RKP) are derivation of the political promises of the Heads of state / Region at the time of the election campaign.

Since National / Regional Development Planning (PPN/D) is a derivation of political promises of the head of state / region, the National and Regional Development Planning tends to be momentary interests of the head of state / region and / or elitists around him. Thus the National and Regional Development Planning which is put into the program and made as a project can be colored by the elements of corruption, collusion and nepotism and that the program / project is likely to be executed at 
random. Of course, the legislation in force in Indonesia has already set on the unlawful acts such as corruption, collusion and nepotism. However, the liability for acts of corruption, collusion, and nepotism that leads to the failure of the National / Regional Development Planning is still noticeably blurry and so light, and limited only when the accountability report of the implementation of the National and Regional Development Planning is declared "rejected", then the head of state/region concerned would be requested to fix it and/ or he could no longer run. On the other hand, the National / Regional Development Planning must have used a large number of resources, so it is interesting to see more deeply, such as the possibility of criminal sanctions which can be imposed as a "deterrent" of a bad faith of the whole process National/Regional Development Planning. Based on the problems mentioned above, this paper will discuss the possibility to request criminal liability for the failure of the National / Regional Development Planning.

Some questions posed as the scope of the discussion are as follows:

1. Who are responsible for the National / Regional Development Planning?

2. What are the measurements of the failure of National / Regional Development Planning?

3. What is the basis of criminal liability for the failure of the National / Regional Development Planning?

\section{THEORETICAL FRAMEWORK}

\subsection{Discourse}

In general, discourse (called "wacana" in Indonesian) means the typical way to speak or use language, both written and spoken. Certain groups of people use the typical language. Medical people, for example, have their own discourse which is different from that owned by legal people. Michael Foucault relates the term of discourse with the creation of knowledge and power relations. He defines it as the language practice used by various constituencies (eg, law, religion, medicine, etc.) for the purposes relating to the power relations in society (Wolfreys, 1999). The definition proposed by Weedon (1987) may be able to better explain what is meant by Foucault. It is stated that discourse is: "... how to construct knowledge, and social practices, forms of subjectivity, and power relations inherent in that knowledge, and the relationship among all of them." Discourse forms the body of knowledge which in turn affects social practices, conception of the self (subjectivity), and power relations formed. Therefore, it can be said that discourse forms the object (ie knowledge) as well as the subject (ie the men who compiled the knowledge and those who are affected by it) (http://teoriteori.blogspot.com/2009/01/foucault-speakdiskursus.html).

\subsection{Criminal Liability}

Criminal liability is sometimes referred to as toereken-baarheid, or criminal responsibility. Criminal liability, in this case, is intended to determine whether a person can be on 
accounted for criminal or not on the action he has done (Romli Atmasasmita, 2000: p .65). In terms of the philosophy of law, one of the great philosophers of the 20th century, Roscoe Pound describe liability as follow; "I ...use simple word" liability "for the situation whereby one may exact legally and other is legally subjected to the exaction". Criminal liability is interpreted by Pound as an obligation to pay recompense which will be accepted by the perpetrator from someone who has been disadvantaged (S.R Sianturi, 1996: p.24)

In the concept of the Criminal Code (KUHP) of 1982-1983, Article 27 states that criminal liability is the continuation of the objective reproach in a criminal offense under the applicable law, objectively to the perpetrator that meets the requirements of the legislation to be subject to punishment for his action (Djoko Prakoso, 1987: p. 75). According to Prodjohamidjojo, a person is committing criminal offense if at the time of offense, in terms of society, it deserves to be censured. Thereby, according to him, someone who gets punishment depends on two things: (1) there must be actions contrary to the law, or in other words, there must be an unlawful element. So, there must be objective element; and (2) there is an element of fault on the perpetrator, either committed intentionally or accidentally, so the unlawful acts can be accounted to him. So, there is a subjective element (Martiman Prodjohamidjojo, 1997: p.31)

\subsection{Development Planning}

Development planning is a system formed from elements of planning and development that includes notions: (1) Planning is a continuous process that involves decisions or choices of using existing resources targeted to achieve certain goals in the future. (LANDSE, 1999), and (2) Development is a series of efforts of growth and changes that is planned and carried out consciously by a nation, State and Government toward modernity in developing the nation for better changes. (Ginanjar Kartasasmita, 1996)

\subsection{Control System}

Control system can be defined as an effort or treatment of a system, with a particular input, to obtain the desired output. Control system is a reciprocal relationship among the components thatmake upa system configuration that provides desired result in the form of response (Dorf, 1983). In other words, control is the process of influencing members of other organizations to implement organizational strategies set. The elements of control system include planning, budgeting, resource allocation, measurement, evaluation and rewards for performance. Furthermore, in the government, there is Government Internal Control System (SPIP). It is an integrated process of actions and activities carried out continuously by management and all employees to provide reasonable assurance on the achievement of organizational goals through effective and efficient activities, reliability of financial reporting, security of State assets, and compliance with laws and regulations (Article 1 Government Regulation (PP) No. 60 of 2008 on Government Internal Control System (SPIP)) 


\section{RESEARCH METHOD}

The method in compiling this paper is qualitative descriptive using secondary data, ie. Literature search in the form of legislation, dictionaries, books, presentation materials, news as well as writings of both contained in the paper and pages related to accountability, criminalization, and National / Regional Development Planning

\section{RESULT AND DISCUSSION 4.1. Man behind the Gun}

Control system must be supported by a good organizational structure. Organizational structure is manifested in the structure of responsibility center. Responsibility center is an organizational unit headed by a manager who is responsible for the overall activities of the organization he leads in order to achieve the goals. An assessment of the performance of a manager is very important because through the performance assessment it can be known whether the manager of the responsibility center implements the authority and responsibility delegated to him. Responsibility of the manager of responsibility center is to create an optimal relationship between resources of inputs used and outputs generated associated with performance targets. Input is measured by the number of resources used, while output is measured by the number of products / output produced.

Indonesia adheres to a presidential system, or also called a congressional system. It is the system of republican government in which the executive power is elected through general election and separated from legislative power,
Jimly Asshiddiqie, 2004. Heads of State and Head of Region are the administrators of all governmental affairs at national and regional levels. Thus, the manager of responsibility center of public organization, or called government, is the Head of State for national level and the Head of Region for the regional level.

The objectives of the establishment of responsibility center are: (1) as the basis for planning, control, and evaluator of manager's performance and the organizational unit he leads; (2) to facilitate in achieving organizational goals; (3) to facilitate the formation of goal congruence; (4) to delegate tasks and responsibilities to units which have competence to reduce the workload of center manager; (5) to encourage creativity and innovation of subordinates; (6) as a means to implement the organizational strategy effectively and efficiently; (7) as a means to control the budget. (http://www.baduttumin. wordpress.com)

Thus, it can be concluded that the man behind the gun of the whole process of National / Regional Development Planning (PPN/D) is the Head of State / Region. Unto them the responsibility of the entire process of National / Regional Development Planning (PPN/D) is requested.

\subsection{Measurements of the Failure of National / Regional Development Planning}

As the consequence of a legal and democratic country, the Head of State / Region in Indonesia has to be responsible for the implementation of 
the governmental affairs and functions either directly or through representatives. Hughes Owen (1992, p. 240) states that government organizations are created by the public, for the public and need to be accountable to it.

For the realization of the implementation and in line with the efforts to create a clean government which is responsible and able to respond to the demands for changes effectively and efficiently in accordance with the principles of good governance, the Head of State / Region is obliged to report the implementation of national and regional governance. One of the principles contained in the modern governance is the existence of "accountability". The power of government must be performed responsibly because the power was born from the people's trust. The power which is obtained from an institution formed democratically, logically, must be accountable to the people. Thus, accountability is an absolute requirement that must be met in democratic government.

Legislation in Indonesia has set up mechanisms for accountability by the Head of State / Region, such as Law No. 32 of 2004 on Regional Implementation Accountability Report (LPPD), Accountability Report (LKPJ); and Regional Implementation Accountability Report (LPPD) information. Regional Head, according to Law No. 32 of 2004 is not responsible to the side or Parliament and to the bottom or electorate or people, but to the top. This means that the governor is responsible to the President through the Minister of Home Affairs, the Head of Regency / City Mayor is responsible to the Minister of Home Affairs through the Governor. The Head of Region only gives a description of accountability to Parliament and conveys information to the public (Article 27). Each Head of State / Region is required to provide accountability reports at the end of his term.

Accountability report as a media of accountability is actually a report of the entire implementation of governance which is started from National/Regional Development Planning (PPN/D). Therefore, the measurement of the failure of National / Regional Development Planning (PPN/D) can be seen through the acceptance or the rejection of the accountability report. If the accountability report is rejected, it can be said that the development planning fails.

\subsection{The Basis of Criminal Liability for the Failure of National / Regional Development Planning}

Sutoro Eko (2007) assessed that the accountability mechanisms, especially the Regional Head, will cause adverse effects. In the context of the structure of bureaucratic and clientelistic political, vertical accountability will make the Regional Head less accountable and responsive to the public. He will be more loyal to his superiors. In practice, the Regional Head will possibly avoid the pressure of the people and public accountability, because he feels that the accountability is only to be delivered to the center. Vertical loyalty will be easily utilized by the Regional Head as a shield against the public demands.

There have never been legal implications conducted by either Parliament or public 
related to the rejection of the Accountability Report presented by the Head of State / Region. Although the Parliament is entitled to give decision on the Accountability Report presented by the Head of State / Region, the decision is merely a recommendation in which its implication is only in the form of inputs to the Head of State / Regional for a better improvement.

Anis Zakaria Kama (2012; p.258) states that there are three kinds of government accountability: political accountability, legal accountability and economic accountability. Actually, if the accountability report of the Head of State / Regional is rejected, as a measurement of the failure of the National and Regional Development Planning, legal liability could be imposed to the Head of State / Regional in the form of punishment. Since the National and Regional Development Planning is a derivation of the political promises of the Heads of State / Regions, the basic charge that can be imposed on the failure of the National and Regional Development Planning is fraud.

In the Criminal Code (KUHP) Book II on assets of crime, fraud is categorized as the form of attacks on individual legal interest on the assets owned. In general, the elements of criminal offense against these assets include objective elements and subjective elements. The objective elements consist of: (1) element of material acts, such as taking (in the case of theft), forcing (in the case of extortion), possessing / claiming (in the case of embezzlement, mobilizing hearts / minds of others (in the case of fraud) and so on;
(2) element of objects / items; (3) element of circumstances that accompany the objects / items that should belong to others; (4) element of specific measures that are used to perform prohibited act; ( 5) constitutive element arising after such a prohibited act. While the subjective elements consist of: (1) element of error which is formulated with words such as "for the purpose of", "intentionally", "known / allegedly" and so on; and (2) element of lawlessness either asserted explicitly or in written in the formulation of the articles or not. (Adami Chazawi, 2006)

The Criminal Code sets the offense of fraud in detail in Book II, Chapter XXV from Article 378 to 395 . The provision concerning the genus of fraud (principal criminal offense) contained in Article 378 of the Criminal Code states as follows: "Any person who intentionally benefit himself or others unlawfully, using a false name or false dignity, deceitfully or by a series of lies mobilize others to surrender anything at him, or in order to give loan or eliminate debt, is threatened due to fraud by imprisonment maximum 4 (four) years".

Based on Article 378 of Criminal Code mentioned above, juridically the offense of fraud must meet the principal elements: 1 . subjective element of offense in the form of deliberate of the perpetrator to deceive others as defined in article of law with the words: "with the intention to benefit himself or others unlawfully"; and 2. objective element of offense consisting of: (a) element of anyone; (b) element of mobilizing others in order to surrender an object / give loan / eliminate debt; 
and (c) elements of the ways to mobilize others using a false name / false dignity or nature / trickery / series of lies

Thus, to be able to declare that a person is a perpetrator of fraud, the Court Judge has to conduct an inspection and prove legally and convincingly that the existence of elements of fraud, both subjective element and objective element, in the self and deeds of the person is proven. This means, in the context of proving subjective element, for example, since the understanding of deliberate of fraud perpetrator (opzet) theoretically includes the meaning of willen en witens (wills and or know), it must be proved that the accused indeed had (PAF Lamintang, 1989; Pg . 142): (a) intended to benefit himself or others unlawfully; (b) "desired" or at least " "known / been aware" that his action from the beginning had been intended to mobilize others in order to surrender an object / give loan / eliminate debt at him (the perpetrator of the offense); (c) "known / been aware" that what he had used to mobilize other people in order to surrender an object / give loan / eliminate debt at him was a false name, false dignity or false nature, trickery or a series of lies.

In actual judicial practice, it is not easy to find the legal facts of the subjective element of the offense, moreover when "the perpetrator" and "the victim" of fraud have laid the foundation of their legal action in the corridor of a pure agreement. Therefore, it is not easy to simply declare that a person has met the subjective element of the offense of fraud just because he had informed prospective business to someone then that person was moved to include the capital in the business. Since the court must still prove that when the person informed prospective business to others, there must also be found the legal facts that he, from the beginning, had intention so that the people who were given the information were mobilized to surrender the item / his property and so on, the business information is false / lie and he, with all of that, intends to benefit himself or others.

In addition, since the nature / qualification of criminal fraud is a formal offense - material, juridically and theoretically, it requires the proof that the victims of fraud in handing an object and so on to the perpetrators should really causality (related to and caused by the ways of the perpetrator) as defined in Article 378 of Criminal Code. And it is certainly not as so simple as in practice in court. Therefore, the reality of a case of tort should not be able to frugally be withdrawn and qualified as a crime of fraud.

Furthermore, since fraud is an offense of complaint, those who have legal standing in case of the failure of the National and Regional Development Planning are Indonesian people.

\section{CONCLUSION AND SUGGESTION 5.1. Conclusion}

As the answers to the problems, the conclusion is as follows:

a. Since the Head of State / Regional serves as the responsibility center of the governance, the Head of State / 
Regional is responsible for the National and Regional Development Planning;

b. The rejection of the accountability reports presented by the Head of State / Region is a measure of the failure of the National and Regional Development Planning;

c. Since, National and Regional Development Planning is a derivation of the political promises of the Head of State / Region at the time of election campaign, the criminal offenses of fraud can be made as the basis of criminal liability for the failure of the National and Regional Development Planning.

\subsection{Suggestion}

a. It is necessary to issue regulations related to the failure of national and regional development planning;

b. The public should have a mechanism whether to accept or to reject the accountability report presented by the Head of State / Region.

\section{REFERENCES:}

Adami Chazawi, Kejahatan terhadap Harta Benda, Bayu Media Publishing, Malang, 2006

Anis Zakaria Kama, 2012, Hakikat Akuntabilitas Dalam Penyelenggaraan Pemerintahan, Disertasi, Program Doktor Ilmu Hukum Pascasarjana Universitas Muslim Indonesia, Makassar

Djoko Prakoso, 1987, Asas-Asas Hukum Pidana di Indonesia, Edisi Pertama, Liberty Yogyakarta, Yogyakarta

Eriyatno, 2002.Strategi Implementasi Program Pengembangan UKM, Presntasi pada Lokakarya Penguatan UKM, Mempercepat Agenda Reformasi Kebijakan

Ginanjar Kartasasmita. Pembangunan Untuk Rakyat Memadukan Pertumbuhan Dan Pemerataan. Jakarta : Cidesindo 1996

Hughes Owen, E., 1992, Publik Management and Administration an Introduction, New York, ST. Martin Press

Jimly Asshiddiqie, 2004,Format kelembagaan negara dan pergeseran kekuasaan dalam UUD 1945, FH UII Press, Jakarta

Martiman Prodjohamidjojo, 1997, Memahami Dasar-Dasar Hukum Pidana Indoesia, PT.Pradnya Paramita, Jakarta

P.A.F Lamintang, 1989, Delik-Delik Khusus Kejahatan terhadap Harta Kekayaan, Sinar Baru, Bandung

Peraturan Pemerintah Nomor 60 Tahun 2008 tentang Sistem Pengendalian Internal Pemerintah

R.C. Dorf, 1983, Sistem Pengaturan, Edisi 3, Erlangga, Jakarta

Romli Atmasasmita, 2000, Perbandingan Hukum Pidana, Cetakatan ke II, Mandar Maju, Bandung

S.R Sianturi, 1996, Asas-asas Hukum Pidana Indonesia dan Penerapanya,Cetakan ke IV, Alumni Ahaem-Peteheam, Jakarta

Sutoro Eko, "Resentralisasi dan Neokorporatisme.” Sumber: http://www. ireyogya.org, 
Taufik Hidayat : Discourse: Criminal Liability For The Failure Of .....

Page 137-146

Undang-undang Nomor 32 Tahun 2004 tentang Pemerintahan Daerah

Undang-Undang Nomor 25 Tahun 2004 tentang Sistem Perencanaan Pembangunan Nasional

Undang-Undang Nomor 1 Tahun 1981 tentang Kitab Undang-Undang Hukum Pidana (KUHP)

Yahya Rachmana Hidayat, 2014, Peningkatan

Kemampuan Perencana, Presentasi pada Kuliah Perdana Magister Administrasi

Publik-Universitas Brawijaya

http://teori-teori.blogspot.com/2009/01/

foucault-speak-diskursus.html

http://www.baduttumin.wordpress.com 